\title{
The Resonance Factor: Probing the Impact of Video on Student Retention in Distance Learning
}

\author{
Nitza Geri \\ The Department of Management and Economics, \\ The Open University of Israel, Raanana, Israel \\ nitzage@openu.ac.il
}

\begin{abstract}
Teaching and instructing is one of the challenging manifestations of informing, within which distance learning is considered harder than face-to-face instruction. Student retention is one of the major challenges of distance learning. Current innovative technologies enable widespread use of video lectures that may ease the loneliness of the distance learner and increase retention. This study explores the impact of video lectures on relatively senior students in a distance-learning environment. The study compares the retention and achievements of overseas students enrolled in a financial theory compulsory course, which is considered difficult. Students tend to study this course only after successfully completing other courses. The results indicate that before the introduction of video most of the students who failed the course dropped out immediately after failing, whereas afterwards nearly all the students who failed the course continued their studies. The main findings suggest that video lectures may increase senior students' retention, although their achievements were not found significantly better than those of distance learners that did not have video lectures available. This paper contributes to the informing science transdiscipline by demonstrating the importance of resonance for effective informing.
\end{abstract}

Keywords: online video lectures, effectiveness of instructional technologies, student retention, distance learning, social aspects of online learning, continued use of information systems, attention economy.

\section{Introduction}

The informing science transdiscipline (Cohen, 1999, 2009; Gill, 2010; Gill \& Cohen, 2009) studies all issues concerned with informing clients. The classic definition of the purpose of informing science is providing clients with information "in a form, format, and schedule that maximizes its effectiveness" (Cohen, 1999). The term client that refers to the recipient of the information is somewhat misleading because it may implicitly imply that the client is a customer of the information sender. However, practically, informing science uses the term clients to describe all sorts of

Material published as part of this publication, either on-line or in print, is copyrighted by the Informing Science Institute. Permission to make digital or paper copy of part or all of these works for personal or classroom use is granted without fee provided that the copies are not made or distributed for profit or commercial advantage AND that copies 1) bear this notice in full and 2) give the full citation on the first page. It is permissible to abstract these works so long as credit is given. To copy in all other cases or to republish or to post on a server or to redistribute to lists requires specific permission and payment of a fee. Contact Publisher@InformingScience.org to request redistribution permission. recipients, such as machines (e.g., computers), customers, patients, students, employees, the general public, business associates, and soldiers who take orders from their commanders.

Teaching and instructing is one of the most challenging manifestations of informing because it involves imparting new knowledge or skills to a learner. The immediate association that comes to 
mind is teachers teaching pupils in schools or students in universities and other higher education institutes. However, business corporations, governmental services, and diverse sorts of other organizations, all need to train their employees and keep them up-to-date with relevant knowledge and skills. Furthermore, lifelong learning is an evolving trend and people seek frameworks of study that will be compatible with their other commitments, such as work and family.

Distance learning enables flexibility of time, place, and pace of learning. Contemporary technologies, particularly instant worldwide connectivity through the internet, provide organizations and individuals with convenient opportunities for deploying distance learning. However, studying, as well as instructing, in a distance-learning environment is considered harder than that con-

ducted in face-to-face frameworks. In educational contexts, student retention has always been one of the major challenges of distance learning (Levy, 2007; Simpson, 2003; Tinto, 1998; Woodley, 2004). Much is attributed to the lack of social interaction, especially the "loneliness of the longdistance learner" (Eastmond, 1995). Current innovative technologies enable widespread use of video lectures (Copley, 2007) that may ease the loneliness of the distance learner, and increase retention.

From the informing science perspective, video lectures may enhance resonance by supporting the social aspects of learning and satisfying the students' need for social interaction. Gill (2008) developed the concept of resonance, based on Cohen's observation that in order to achieve effective informing, the sender must understand not only the task, but also the client's psychology (Cohen, 1999). Following this observation, Gill \& Bhattacherjee $(2007,2009)$ argued, in the context of academic research, that besides rigor (i.e., research quality from a discipline's perspective) and relevance (i.e., the potential utility of the research to client activities), resonance is necessary for effective informing. Resonance is defined by Gill (2008) as the ability to impact client mental models. Gill (2008) indicates several filters that can interfere with resonance, and the type of filters that is most relevant in the context of this study is visceral filters, such as emotions and moods. The relatively rich medium of video lectures as opposed to written text may help to overcome such filters.

This study contributes to the informing science transdiscipline by demonstrating the importance of resonance for effective informing in distance learning environments. The study explores the impact of video lectures on relatively senior students in a distance-learning environment. Student dropout in distance learning frameworks is a multifaceted issue (Woodley, 2004). However, as students progress in their studies their tendency to quit decreases (Geri \& Gefen, 2007; Simpson, 2003). Therefore, this study examined relatively senior students who have already proven their ability to learn in a distance learning mode and successfully completed on average about 7-8 courses. The research compared the retention and achievements of overseas students enrolled in a financial theory compulsory course, which is considered difficult. The results indicated that before the introduction of video most of the students who failed the course dropped out immediately after failing, whereas afterwards nearly all the overseas students who failed the course continued their studies.

The following section provides the theoretical context of this study and reviews various elearning methods that attempt to deal with the social needs of students in distance learning environments. Subsequently, the research methodology and results are presented, followed by discussion of the theoretical and practical implications of the findings. This paper concludes with the observation that although the availability of video lectures has not significantly affected overseas students' achievements, by attending to their need for social interaction, it might have increased resonance (Gill, 2008) and improved student retention. 


\section{Theoretical Context: Social Interaction in Distance Learning}

The importance of social interaction in distance learning is well recognized (e.g., Salmon, 2004), and has been widely studied. The concept of distance learning is not new. Distance education has been around at least since the late years of the $19^{\text {th }}$ century and was based on correspondence via mail (Moore \& Kearsley, 2011). As more communication channels and technologies, such as radio and television, were developed and became ubiquitous, they have also been used for distance education. However, the internet has provided distance education with much more powerful communication channels and increased its potential use. Online learning has grown considerably in recent years, and it is used in many academic institutions, at least partially, instead of face-toface instruction (Hiltz \& Turoff, 2005). Nevertheless, not enough thought has been given to the implications of this fundamental change (Hirschheim, 2005), particularly to high dropout rates, which is a primary challenge of distance learning (Simpson, 2003; Tinto, 1998; Woodley, 2004).

An online submission assignment system is a relatively simple tool that improves communication between distance learning students and instructors. However, some instructors may not encourage the use of such online submission assignment systems because it may not be convenient to read the assignments, or write comments, online (Geri \& Naor-Elaiza, 2008).

Social interaction is considered as one of the main ways to increase student retention in distance learning (Guri-Rosenblit, 2005). Discussion boards are regarded as a principal means of elearning (Harman \& Koohang, 2005), since they enable various sorts of communication between tutors and their students, as well as among students, and seemingly replace regular class discussions. Unfortunately, students tend not to participate in a threaded discussion unless they are obliged to do so (Wishart \& Guy, 2009). Notwithstanding, students like to read other students' posts, so the number of views is much larger than the extent of posts (Saade \& Huang, 2009).

Another important trend, which is aimed at increasing social interaction among students, is collaborative tasks. These tasks require much more effort from both the students and the instructors. The main collaborative online tools are wikis (Wheeler, Yeomans, \& Wheeler, 2008), blogs (Blau, Mor, \& Neuthal, 2009), and GoogleDocs (Caspi \& Blau, 2011; Rimor, Rosen, \& Naser, 2010).

Finally, there are video lectures, which can be synchronous or asynchronous. Whereas participation in synchronous video sessions seems to be more interactive, asynchronous video sessions provide the learners with the opportunity to select the time, place, and pace of learning that fit their individual needs. Current technologies render video use readily available at low production and consumption costs (Copley, 2007), and these factors are anticipated to increase their use for both distance learning and supplementing regular in-class learning.

Although video lectures usually offer students a rich learning experience, such as in regular faceto-face classes, prior studies show that most students prefer traditional in-class studying, even when they are offered a rich e-learning environment that includes video lectures, exercises, and personal online tutoring (Guri-Rosenblit, 2005). It seems that the essential human need to socialize has a major influence on student preferences. However, for those students who cannot attend class, video lectures may be very helpful (Wieling \& Hofman, 2010). Few studies investigate the use of video for learning. There are two studies, one by Whatley and Ahmad (2007) and the second by Brecht and Ogilby (2008), which examine the use of video lectures to support a traditional classroom course. In both studies, the videos helped the students to successfully complete the course.

Table 1 summarizes major levels of social interaction in distance learning. It describes types of interaction, maps the participants in the communication process of each type, indicates the mode 
of interaction (personal versus group), publicity (personal versus public content available to all the students in the group), and lists comments.

\begin{tabular}{|c|c|c|c|c|}
\hline \multicolumn{5}{|c|}{ Table 1: Levels of social interaction in distance learning } \\
\hline Types of interaction & $\begin{array}{l}\text { Participants in the } \\
\text { communication }\end{array}$ & $\begin{array}{l}\text { Mode of } \\
\text { interaction }\end{array}$ & Publicity & Comments \\
\hline $\begin{array}{l}\text { Student submits an as- } \\
\text { signment and gets per- } \\
\text { sonal feedback from } \\
\text { the tutor (via mail, e- } \\
\text { mail, or designated sys- } \\
\text { tem) }\end{array}$ & Tutor and student & Personal & Personal & $\begin{array}{l}\text { The main type of stu- } \\
\text { dent-tutor interaction } \\
\text { prior to the arrival of } \\
\text { course websites. }\end{array}$ \\
\hline $\begin{array}{l}\text { Student submits an as- } \\
\text { signment and gets per- } \\
\text { sonal feedback from } \\
\text { the tutor; the assign- } \\
\text { ment is posted at the } \\
\text { course website }\end{array}$ & Tutor and student & Personal & Public & $\begin{array}{l}\text { Improves quality of } \\
\text { students' work, and } \\
\text { their learning. They try } \\
\text { harder, since their } \\
\text { work is published. }\end{array}$ \\
\hline \begin{tabular}{|l} 
Student posts a ques- \\
tion on a course discus- \\
sion board, and the tu- \\
tor answers it
\end{tabular} & $\begin{array}{l}\text { Student and tutor (gen- } \\
\text { erally, most postings } \\
\text { are answered by the } \\
\text { tutor) }\end{array}$ & Personal & Public & $\begin{array}{l}\text { Most students read the } \\
\text { posts, thus passive par- } \\
\text { ticipants also gain } \\
\text { benefits. }\end{array}$ \\
\hline $\begin{array}{l}\text { Threaded discussions } \\
\text { (as a course assign- } \\
\text { ment) }\end{array}$ & $\begin{array}{l}\text { Students (tutor usually } \\
\text { moderates the discus- } \\
\text { sions) }\end{array}$ & Group & Public & $\begin{array}{l}\text { Considered as the main } \\
\text { tool of social interac- } \\
\text { tion in distance e- } \\
\text { learning. } \\
\text { Students tend not to } \\
\text { participate in a } \\
\text { threaded discussion } \\
\text { unless they are } \\
\text { obliged. }\end{array}$ \\
\hline $\begin{array}{l}\text { Collaborative task - } \\
\text { students are assigned to } \\
\text { small groups }\end{array}$ & $\begin{array}{l}\text { Students (tutor usually } \\
\text { moderates the activity) }\end{array}$ & Small & Public & $\begin{array}{l}\text { Requires much effort. } \\
\text { Main tools: Wiki, } \\
\text { blogs, Google Docs. }\end{array}$ \\
\hline $\begin{array}{l}\text { Asynchronous video } \\
\text { lectures }\end{array}$ & Tutor provides content & Impersonal & Public & $\begin{array}{l}\text { Student watches alone, } \\
\text { flexibility of time, } \\
\text { space, and pace. }\end{array}$ \\
\hline $\begin{array}{l}\text { Synchronous video } \\
\text { sessions or other tools } \\
\text { that enable group } \\
\text { communication, e.g., } \\
\text { Elluminate }\end{array}$ & Tutor and students & Group & Public & $\begin{array}{l}\text { Many students prefer } \\
\text { to watch the videos } \\
\text { asynchronously, if they } \\
\text { are available. }\end{array}$ \\
\hline
\end{tabular}


Another important aspect that should be kept in mind is the essentiality of active learning Zhang, Zhou, Briggs, and Nunamaker (2006). The students should be discouraged from just passively watching the videos, because is not cognitively captivating and challenging, and therefore it is less effective for learning (Cherrett, Wills, Price, Maynard, \& Dror, 2009). These learning activities, which are intended to challenge the viewers and make them cognitively effective, may not necessarily involve the tutor who recorded the video (Dror, Schmidt, \& O'connor, 2011). Such activities may include taking notes, answering online quizzes, or preparing assignments. Zhang et al. (2006) compared three e-learning environments and one traditional classroom setting, and found that the effectiveness of video learning was contingent upon providing the students with interactive video sessions.

\section{Methodology}

The purpose of this study is to contribute to the informing science transdiscipline by empirically demonstrating the importance of resonance (Gill, 2008), specifically social interaction through asynchronous video lectures, for effective informing in distance learning environments. In order to achieve this aim, the study analyzed the impact of video lectures on the retention and achievements of relatively senior overseas students in a distance-learning environment. Since there is very little prior research on this matter, the nature of this study is exploratory.

The study took place at the Open University of Israel, which is a distance-learning institute with about 43,000 undergraduate students and 3,500 graduate students (Open University President's report, 2010). The Open University's credo is open admission and academic excellence. Every year, the university recruits $11,000-12,000$ new students. However, many of them drop out at the beginning of their studies because they are unable to meet the academic requirements. As mentioned above, many factors influence student retention in distance learning frameworks (Simpson, 2003; Woodley, 2004). Nonetheless, it is known that as students progress in their studies their tendency to quit decreases (Geri \& Gefen, 2007). In order to reduce the possible influence of other effects that may cause student dropout, this study examined relatively senior students who have already proven their ability to learn in a distance learning mode and have successfully completed on average about 7-8 courses.

A prior exploratory study (Geri, 2011), which was conducted at the Open University of Israel, examined the adoption of interactive online video-based distance learning in two introductory courses during the first six semesters in which this option was offered. Only $7 \%$ of the actual 19,000 student enrollment decisions were to enroll to the interactive video-based study group. Although the video lectures were perceived excellent, these results demonstrated that students preferred face-to-face learning. Further examination of the video lectures' impact on the achievements and perseverance of overseas students did not reveal statistically significant improvement in their performance. Geri (2011) suggested that these findings might be attributed to the introductory nature of the examined courses, and they might not be applicable to more advanced courses, or to more experienced students. Therefore, as already mentioned above, the current study investigates overseas senior students.

The Open University offers its students the choice of a full distance-learning model or a blended learning model. Students who choose the blended model combine face-to-face meetings with online support through course websites, which supplement traditional means of distance education, such as books and study guides. During the last three years, video lectures were gradually introduced in some of the courses. The videos were uploaded to the course websites and were available to all the students enrolled on these courses. Overseas students were chosen for this study, and not the overall population of the students enrolled in a certain course, because they were unable to attend traditional class meetings. Local students, who were enrolled to traditional classes, may have watched the videos as well as attending face-to-face class meetings, or may 
have chosen after the fact, to abandon their class and study just from the videos. Some local students, as well as overseas students, may have chosen not to watch the videos at all.

Generally, all the students were expected to have a positive attitude with regard to the video lectures, as suggested by a study of general attitudes of students toward video lectures in ten courses, which was conducted at the Open University of Israel (Steimberg et al., 2010). The study indicated that $93.6 \%$ of the students thought that watching the videos might improve their understanding of the learning materials. However, Steimberg et al. (2010) measured perceptions and their study was based on a sample of students who answered a survey, whereas this study measures actual individual students' grades and their retention records.

The research population of this study was comprised of overseas students enrolled in a financial theory compulsory course. Although it is a regular course, it is considered difficult. Most students tend to study this course only after successfully completing several other courses. The course is offered by the department of management and economics, and, in accordance with the open admission and academic excellence policy of the Open University, there are no prerequisites to this undergraduate course (anybody may enroll). However, students are advised to take this financial theory course only after studying four introductory courses: two introductions to economics and two introductions to statistics.

During the years 2010 and 2011, the course was offered twice each year, and in each semester, 1,000 to 1,200 students have studied it. The course was not offered during the shorter summer semester. About two thirds of those who take the course eventually complete it successfully. Some of them fail the first time they take the exam and pass on the second time. Others have to take the course twice. Those who do not succeed either change their program of studies or quit.

Interactive video conference lectures were introduced in the financial theory course in semester 2010A. The video lectures were given by the course coordinator, who is responsible for organizing and managing the instruction process and is an excellent as well as experienced tutor. The video lectures were complete class sessions, so the overseas students could see the instructor, as well as some students who attended the video sessions, and hear the interaction that took place in the class. Other available options for communication and social interaction that overseas students could use included the discussion board on the course website, as well as chat, e-mail connection with the instructor, and written feedback on their assignments.

The analysis compared data of 32 overseas students who were enrolled in the financial theory course during the first four semesters in which the video lectures were offered (i.e., semesters 2010A, 2010B, 2011A, 2011B) with data of 32 overseas students who took the course previously (during semesters 2006A, 2006B, 2007A, 2007B, 2008A, 2008B). The students who took the course in 2009 were excluded since in this year there were exogenous circumstances that might have affected the students' achievements. The total of 64 students is all the overseas students who were enrolled in the financial theory course during the years 2006-2011 (excluding 2009). None of these students took the course twice, but some of them dropped out, as reported in the results section.

Students who were enrolled in an interactive video group and overseas students were entitled to participate in a live video session. They could watch the session anywhere via the internet on their personal computer screen, communicate (e.g., ask questions) in real time with the instructor mainly through chat or phone, and get their answers during the same video session. The students could also choose just to watch the recording, which was posted on the course website about a day after the session took place. Most of the overseas students probably watched the recordings, due to being in different time zones or for other reasons. The proportion of students who participated in the interactive video sessions, out of those who were entitled to do so, varied, and usually was around $30 \%$ in regular sessions during the semester. It should be pointed out that many of the 
Open University's students work, and one of their reasons for choosing to study at this university is that they are not obliged to attend class meetings. Their only obligation to physical presence is when taking the course final exam at the end of the semester.

It was impractical to compare the achievements and retention of all the thousands of students who took this course in a blended learning environment with those of overseas students. Furthermore, the population of students who take this course in a blended learning environment is heterogeneous and differs in many aspects from the population of overseas students. Nevertheless, two faceto-face study groups were sampled, one group before the introduction of video lectures, and one

afterwards. Both control groups were instructed by the same tutor as the one who taught the video lectures. The group from semester 2007A had 29 students, and the group from semester 2010B had 35 enrolled students. Two aspects were examined: the proportion of students who failed the course and their retention.

\section{Results}

Table 2 presents the overseas students' demographics and descriptive data regarding their general achievements, as well as their achievements in the financial theory course. It is evident that the two groups of students, those who took the course before the introduction of video lectures and those who took it afterwards, are very similar in all the analyzed aspects, except for one - student retention. As shown on the last row of Table 2, out of seven students who failed the final exam before the availability of video lectures, six students dropped out immediately and did not enroll in other courses at the Open University. Further probing of the data revealed that although the two other students who dropped out passed the financial theory course, their grades in this course were very low (just under $60 \%$ ), whereas their average grade in all their other courses was almost $80 \%$. Thus, eight overseas students dropped out of their studies at the Open University due to their unsuccessful experience in studying the financial theory course before the availability of video lectures. On the contrary, after the introduction of video lectures, although there were eight students who had not passed the course, none of them dropped out.

The overseas students were compared with two sample local groups of students who had chosen the blended learning option and were instructed face-to-face by the same tutor of the video lectures. The results are presented in Table 3. Interestingly, all the seven students who took the faceto-face course in 2007A and failed continued their studies immediately after the failure. Five of them withdrew several semesters afterwards but it may be due to other reasons, including failure in other courses. The other two students continued their studies, but so far, they have not attempted to repeat this course. One other student who passed the course, dropped out immediately afterwards probably due to other reasons. When comparing this group to the overseas students group before the introduction of video lectures, it is evident that those who failed reacted differently: most of those abroad dropped out immediately, while the locals continued their studies, at least for the short run.

However, when comparing the data in Table 3 of the local 2010B blended group with the overseas students group after the introduction of video lectures, the picture looks a bit different. Of the local group with 35 students, $14(40 \%)$ had failed the course, and four of them (11.4\% of the total enrolled, or $28.5 \%$ of those who failed) withdrew immediately. As already mentioned, none of the overseas students withdrew. This issue is discussed further in the following section. 


\begin{tabular}{|c|c|c|c|}
\hline \multicolumn{4}{|c|}{$\begin{array}{l}\text { Table 2: Overseas students' demographics and achievements } \\
\text { in a compulsory undergraduate financial theory course }\end{array}$} \\
\hline & $\begin{array}{l}\text { Before introduction } \\
\text { of video lectures }\end{array}$ & $\begin{array}{l}\text { After introduction of } \\
\text { video lectures }\end{array}$ & Comments \\
\hline Semesters & $\begin{array}{l}2006 \mathrm{~A}, 2006 \mathrm{~B}, 2007 \mathrm{~A} \\
2007 \mathrm{~B}, 2008 \mathrm{~A}, 2008 \mathrm{~B}\end{array}$ & $\begin{array}{l}2010 \mathrm{~A}, 2010 \mathrm{~B}, 2011 \mathrm{~A} \\
2011 \mathrm{~B}\end{array}$ & \\
\hline Number of students & 32 & 32 & \\
\hline Gender & $\begin{array}{l}15 \text { Men }(46.9 \%) \\
17 \text { Women }(53.1 \%)\end{array}$ & $\begin{array}{l}12 \text { Men }(37.5 \%) \\
20 \text { Women }(62.5 \%)\end{array}$ & \\
\hline $\begin{array}{l}\text { Average age when } \\
\text { taking the course }\end{array}$ & 31 years old $(\mathrm{SD}=4.8)$ & 30 years old $(\mathrm{SD}=4.4)$ & \\
\hline $\begin{array}{l}\text { Average credit points } \\
\text { earned before enrolling } \\
\text { to the course }\end{array}$ & 44.3 points $(\mathrm{SD}=23.8)$ & 51.4 points $(\mathrm{SD}=28.8)$ & $\begin{array}{l}\text { Excluding accreditation for } \\
\text { prior studies that was negli- } \\
\text { gible. }\end{array}$ \\
\hline $\begin{array}{l}\text { Average current credit } \\
\text { points earned (as of } \\
\text { 2011C) }\end{array}$ & 81.4 points $(\mathrm{SD}=34.0)$ & 67.2 points $(\mathrm{SD}=34.7)$ & $\begin{array}{l}\text { Those who studied the } \\
\text { course before the introduc- } \\
\text { tion of video lectures started } \\
\text { their studies earlier. }\end{array}$ \\
\hline $\begin{array}{l}\text { Average current grade } \\
\text { (as of 2011C) }\end{array}$ & $79.1(\mathrm{SD}=6.0)$ & $78.2(\mathrm{SD}=6.8)$ & \\
\hline $\begin{array}{l}\text { Average exercise } \\
\text { points earned }\end{array}$ & $15.2(\mathrm{SD}=5.6)$ & $15.8(\mathrm{SD}=6.3)$ & \\
\hline $\begin{array}{l}\text { Average number of } \\
\text { final exams taken }\end{array}$ & $1.1(\mathrm{SD}=0.6)$ & $1.0(\mathrm{SD}=0.6)$ & $\begin{array}{l}\text { Students may take up to two } \\
\text { final exams in each course. } \\
\text { Some students are still enti- } \\
\text { tled to take another exam. }\end{array}$ \\
\hline $\begin{array}{l}\text { Average final exam } \\
\text { grade }\end{array}$ & $70.6(\mathrm{SD}=10.1)$ & $71.1(\mathrm{SD}=13.1)$ & $\begin{array}{l}\text { Only of those who passed } \\
\text { the course. }\end{array}$ \\
\hline $\begin{array}{l}\text { Average final course } \\
\text { grade }\end{array}$ & $72.2(\mathrm{SD}=8.9)$ & $74.0(\mathrm{SD}=12.3)$ & $\begin{array}{l}\text { Only of those who passed } \\
\text { the course. }\end{array}$ \\
\hline $\begin{array}{l}\text { Success: Students who } \\
\text { passed the course }\end{array}$ & 25 students $(78.1 \%)$ & 24 students $(75 \%)^{1}$ & $\begin{array}{l}\text { Some of the students are } \\
\text { still entitled to take the } \\
\text { exam, so the actual success } \\
\text { rate may increase. }\end{array}$ \\
\hline $\begin{array}{l}\text { Failure: Students who } \\
\text { did not pass the course }\end{array}$ & 7 students $(21.9 \%)$ & 8 students $(25 \%)^{1}$ & \\
\hline Dropout $^{2}$ & 8 students $(25 \%)^{3}$ & No students $(0 \%)$ & $\begin{array}{l}{ }^{2} \text { Refers to students who } \\
\text { dropped out immediately } \\
\text { after taking the course. } \\
3 \text { Out of } 7 \text { who failed, } 6 \\
\text { students dropped out imme- } \\
\text { diately. }\end{array}$ \\
\hline
\end{tabular}




\begin{tabular}{|l|l|l|l|l|}
\hline \multicolumn{5}{|c|}{$\begin{array}{c}\text { Table 3: Comparison of overseas students and local students } \\
\text { in a compulsory undergraduate financial theory course }\end{array}$} \\
\hline & \multicolumn{2}{|c|}{$\begin{array}{c}\text { Before introduction of } \\
\text { video lectures }\end{array}$} & \multicolumn{2}{c|}{$\begin{array}{c}\text { After introduction of } \\
\text { video lectures }\end{array}$} \\
\hline & Overseas & Local & Overseas & Local \\
\hline Semesters & $\begin{array}{l}2006 \mathrm{~A}, 2006 \mathrm{~B}, \\
2007 \mathrm{~A}, 2007 \mathrm{~B}, \\
2008 \mathrm{~A}, 2008 \mathrm{~B}\end{array}$ & $2007 \mathrm{~A}$ & $\begin{array}{l}2010 \mathrm{~A}, 2010 \mathrm{~B}, \\
2011 \mathrm{~A}, 2011 \mathrm{~B}\end{array}$ & $2010 \mathrm{~B}$ \\
\hline Number of students & 32 & 29 & 32 & 35 \\
\hline $\begin{array}{l}\text { Success: Students who } \\
\text { passed the course }\end{array}$ & 25 students & $\begin{array}{l}22 \text { students } \\
(75.8 \%)\end{array}$ & $\begin{array}{l}24 \text { students } \\
(75 \%)\end{array}$ & $\begin{array}{l}21 \text { students } \\
(60.0 \%)\end{array}$ \\
\hline $\begin{array}{l}\text { Failure: Students who } \\
\text { did not pass the course }\end{array}$ & 7 students & $\begin{array}{l}7 \text { students } \\
(34.1 \%)\end{array}$ & $\begin{array}{l}8 \text { students } \\
(25 \%)\end{array}$ & $\begin{array}{l}14 \text { students } \\
(40.0 \%)\end{array}$ \\
\hline Immediate dropout & 8 students $(25 \%)$ & $\begin{array}{l}1 \text { student } \\
(3.4 \%)\end{array}$ & $\begin{array}{l}\text { No students } \\
(0 \%)\end{array}$ & $\begin{array}{l}4 \text { students } \\
(11.4 \%)\end{array}$ \\
\hline Total known dropout & 8 students $(25 \%)$ & $\begin{array}{l}6 \text { students } \\
(20.7 \%)\end{array}$ & $\begin{array}{l}\text { No students } \\
(0 \%)\end{array}$ & $\begin{array}{l}5 \text { students } \\
(14.3 \%)\end{array}$ \\
\hline
\end{tabular}

\section{Discussion}

\section{Theoretical Implications, Limitations, and Further Research}

The theoretical purpose of this exploratory study was to empirically demonstrate the necessity of resonance (Gill, 2008) for effective informing. In order to do so, this study investigated the impact of video lectures on relatively senior students in a distance-learning environment. These students had already proven their ability for academic studies, as well as their perseverance by successfully completing on average at least seven courses. Therefore, it was surprising to find out that before the introduction of video lectures, most of these overseas students who failed the compulsory financial theory course, dropped out immediately after failing. Undergraduate students are entitled to two attempts to pass the final exam of each course. As shown in Table 2, the average number of final exams taken by all the students included in the sample was $1.1(\mathrm{SD}=0.6)$. Further examination of the data revealed that none of those who failed the course took two exams. Actually, only three of them took one exam, and the others did not even try it once.

The obvious limitation of this study is the small sample size: two groups with 32 overseas students in each one of them. The sample included all the overseas students who were enrolled in this course during the years 2006-2011 (excluding 2009). Replication of this study in other courses, schools, and learning environments is required to corroborate its findings. Nevertheless, the fact that before the introduction of video lectures practically all of those who failed dropped out, while afterwards none of those who failed withdrew, suggests that video lectures may enhance student retention in distance learning environments.

Even more interesting is the finding that the video lectures did not have much influence on the overseas students' achievements. The proportion of the failures was similar in both groups, about $25 \%$. The average final exam grade was practically the same: $70.6(\mathrm{SD}=10.1)$ before, and 71.1 $(\mathrm{SD}=13.1)$ after. The students' proclivity to submit assignments was similar. The combination of the strong effect of the video lectures on retention and the virtually no effect on students' achievements suggests that the videos enhanced resonance. Many questions require further research, such as: 
- Why apparently the videos did not affect learning?

- How did the videos increase resonance? Was it the social presence of the tutor? Was it due to a sense that the university tries to provide the students with more helpful means of learning?

The comparison with the two control groups of local students, who studied in a blended mode, raises further questions. It seems that the availability of videos on the course website might have had a negative effect on the local students. There are anecdotal reports that local students tend to skip more face-to-face sessions because they rely on the videos. From an attention economy perspective (Davenport \& Beck, 2000, 2001; Geri, Neumann, Schocken, \& Tobin, 2008), it may be harder to concentrate while watching the videos. It might be even harder to find the time to watch them, thus, causing students to procrastinate this task until the end of the semester (Ariely \& Wertenbroch, 2002; Gafni \& Geri, 2010), and then become overloaded. These issues are important directions for further study.

\section{Practical Implications}

The findings of this study suggest that video lectures may be a helpful means for increasing student retention in a full distance-learning environment. However, the effective deployment of this tool requires further experimenting, as well as academic research and practical evaluations.

According to prior research (Guri-Rosenblit, 2005, 2009A, 2009B), most students prefer the hybrid types of courses that combine new technologies, such as video, with conventional learning methods, and only those who cannot attend face-to-face class meetings choose distance-learning modes. The observations of the two local control groups suggest that further work is required to ensure effective integration of video lectures in blended learning settings.

\section{Conclusion}

Instructing in a full distance-learning framework is a considerable informing challenge. Although this mode of learning has been around for more than a century, student retention is a major problem, and the search for effective distance learning methods continues. Video lectures seem to be a promising tool for improving distance learning, especially by catering to the social aspects of the learning process.

This exploratory paper demonstrates the importance of resonance (Gill, 2008) for effective informing. It also suggests some directions for further research of this emerging topic. The study compares the retention and achievements of overseas students enrolled in a financial theory compulsory course, before and after the introduction of video lectures. The main findings indicate that before the use of video lectures most of those who failed the course withdrew their studies immediately after failing, whereas afterwards nearly all the students who failed the course continued their studies. Although the availability of video lectures has not significantly affected the achievements of overseas students, it might have improved their retention. Apparently, this was achieved by attending to their need for social interaction, even though they did not actively participate in the interaction and might have mainly just watched the instructor, it increased resonance, and thus improved their retention.

\section{Acknowledgements}

The author is grateful to Sharon Shafran of the department of Management and Economics, the Open University of Israel, for her cooperation and insightful comments. 


\section{References}

Ariely, D., \& Wertenbroch, K. (2002). Procrastination, deadlines, and performance: Self-control by precommitment. Psychological Science, 13(3), 219-224.

Blau, I., Mor, N., \& Neuthal, T. (2009). Open the windows of communication: Promoting interpersonal and group interactions using blogs in higher education. Interdisciplinary Journal of E-Learning and Learning Objects, 5, 233-246. Retrieved from http://ijklo.org/Volume5/IJELLOv5p233-246Blau667.pdf

Brecht, H. D, \& Ogilby, S. M. (2008). Enabling a comprehensive teaching strategy: Video lectures. Journal of Information Technology Education, 7, 71-86. Retrieved from http://jite.org/documents/Vol7/JITEV7IIP071-086Brecht371.pdf

Caspi, A., \& Blau, I. (2011). Collaboration and psychological ownership: How does the tension between the two influences perceived learning? Social Psychology of Education, 14(2), 283-298. Retrieved from http://www.openu.ac.il/Personal_sites/avner-caspi/Download/Caspi_Blau2011.pdf

Cherrett, T., Wills, G., Price, J., Maynard, S., \& Dror, I. E. (2009). Making training more cognitively effective: Making videos interactive. British Journal of Educational Technology, 40(6), 1124-1134. doi: $10.1111 / \mathrm{j} .1467-8535.2009 .00985 . \mathrm{x}$

Cohen, E. (1999). Reconceptualizing information systems as a field of the transdiscipline informing science: From ugly duckling to swan. Journal of Computing and Information Technology, 7(3), 213-219.

Cohen, E. (2009). A philosophy of informing science. Informing Science: the International Journal of an Emerging Transdiscipline, 12, 1-15. Retrieved from http://inform.nu/Articles/Vol12/ISJv12p001015Cohen399.pdf

Copley, J. (2007). Audio and video podcasts of lectures for campus-based students: Production and evaluation of student use. Innovations in Education and Teaching International, 44(4), 387-399. doi:10.1080/14703290701602805.

Davenport, T. H., \& Beck, J. C. (2000). Getting the attention you need. Harvard Business Review, 78(5), 118-126.

Davenport, T. H., \& Beck, J. C. (2001). The attention economy: Understanding the new currency of business. Boston, MA: Harvard Business School Press.

Dror, I., Schmidt, P., \& O'connor, L. (2011). A cognitive perspective on technology enhanced learning in medical training: Great opportunities, pitfalls and challenges. Medical Teacher, 33(4), 291-296. doi:10.3109/0142159X.2011.550970

Eastmond, D. V. (1995). Alone but together: Adult distance study through computer conferencing. Cresskill, NJ: Hampton Press.

Gafni, R., \& Geri, N. (2010). Time management: Procrastination tendency in individual and collaborative tasks. Interdisciplinary Journal of Information, Knowledge, and Management, 5, 115-125. Retrieved from http://www.ijikm.org/Volume5/IJIKMv5p115-125Gafni448.pdf

Geri, N. (2011). If we build it, will they come? Adoption of online video-based distance learning. Interdisciplinary Journal of E-Learning and Learning Objects, 7, 225-234. Available at http://www.ijello.org/Volume7/IJELLOv7p225-234Geri764.pdf

Geri, N., \& Gefen, D. (2007). Is there a value paradox of e-learning in MBA programs? Issues in Informing Science and Information Technology, 4(1), 163-174. Retrieved from http://proceedings.informingscience.org/InSITE2007/IISITv4p163-174Geri322.pdf

Geri, N., \& Naor-Elaiza, O. (2008). Beyond adoption: Barriers to an online assignment submission system continued use. Interdisciplinary Journal of E-Learning and Learning Objects, 4, 225-241. Retrieved from http://ijello.org/Volume4/IJELLOv4p225-241Ger476.pdf

Geri, N., Neumann, S., Schocken, R., \& Tobin, Y. (2008). An attention economy perspective on the effectiveness of incomplete information. Informing Science Journal: the International Journal of an Emerg- 
ing Transdiscipline, 11, 1-15. Retrieved from http://inform.nu/Articles/Vol11/ISJv11p001-015Geri509.pdf

Gill, T. G. (2008). The single client resonance model: Beyond rigor and relevance. Informing Science: the International Journal of an Emerging Transdiscipline, 11, 281-310. Retrieved from http://inform.nu/Articles/Vol11/ISJv11p281-310Gill222.pdf

Gill, T. G. (2010). Informing business: Research and education on a rugged landscape. Santa Rosa, CA: Informing Science Press.

Gill, T. G., \& Bhatacherjee, A. (2007). The informing sciences at a crossroads: The role of the client. Informing Science: the International Journal of an Emerging Transdiscipline, 10, 17-39. Retrieved from http://inform.nu/Articles/Vol10/ISJv10p017-039Gill317.pdf

Gill, T. G., \& Bhattacherjee, A. (2009). Whom are we informing? Issues and recommendations for MIS research from an informing science perspective. MIS Quarterly, 33(2), 217-235.

Gill, T. G., \& Cohen, E. (Eds.). (2009). Foundations of informing science, 1999-2008. Santa Rosa, CA: Informing Sciences Press.

Guri-Rosenblit, S. (2005). Eight paradoxes in the implementation process of e-learning in higher education. Higher Education Policy, 18(1), 5-29.

Guri-Rosenblit, S. (2009A). Distance education in the digital age: Common misconceptions and challenging tasks, Journal of Distance Education, 23(2). Retrieved from http://www.jofde.ca/index.php/jde/article/view/627/886

Guri-Rosenblit, S. (2009B). Digital technologies in higher education: Sweeping expectations and actual effects. New York, NY: Nova Science Publishers.

Harman, K., \& Koohang, A. (2005). Discussion board: A learning object. Interdisciplinary Journal of Knowledge and Learning Objects, 1, 67-77. Retrieved from http://ijello.org/Volume1/v1p067077Harman.pdf

Hiltz, S. R., \& Turoff, M. (2005). Education goes digital: The evolution of online learning and the revolution in higher education. Communications of the ACM, 48(10), 59-64.

Hirschheim, R. (2005). The internet-based education bandwagon: Look before you leap. Communications of the $A C M, 48(7), 97-101$.

Levy, Y. (2007). Comparing dropouts and persistence in e-learning courses. Computers \& Education, $45(2), 185-204$

Moore, M., \& Kearsley, G. (2011). Distance education: A systems view of online learning (3rd ed.). Belmont, CA: Wadsworth Publishing.

Open University President's report (2010). The President's report 2009-2010. The Open University of Israel. Retrieved from http://www-e.openu.ac.il/presidents-office/report2010E/report2010E.html

Rimor, R., Rosen, \& Naser, (2010). Complexity of social interactions in collaborative learning: The case of online database environment. Interdisciplinary Journal of E-Learning and Learning Objects, 6, 355365. Retrieved from http://www.ijello.org/Volume6/IJELLOv6p355-365Rimor711.pdf

Saadé, G. R., \& Huang, Q. (2009). Meaningful learning in discussion forums: Towards discourse analysis. Issues in Informing Science and Information Technology, 6, 87-99. Retrieved from http://iisit.org/Vol6/IISITv6p087-099Saade675.pdf

Salmon, G. (2004). E-moderating: The key to teaching and learning online (2nd ed.). London, UK: RoutledgeFalmer, Taylor and Francis Group.

Simpson, O. (2003). Student retention in online, open and distance learning, London and Sterling, VA: Kogan Page.

Steimberg, Y., Guterman, E., Mermelstein, B., Brickner, R., Alberton, Y., \& Sagi, R. (2010). Students' perspective on teaching and learning with video technology at the Open University of Israel. In Y. 
Eshet-Alkalai, A. Caspi, S. Eden, N. Geri, \& Y. Yair (Eds.), Learning in the Technological Era: Proceedings of the Chais Conference on Instructional Technologies research (pp. 186H-194H). Raanana, Israel: The Open University of Israel. [in Hebrew] Retrieved from http://telem-pub.openu.ac.il/users/chais/2009/evening/3 1.pdf http://telempub.openu.ac.il/users/chais/2010/after_noon/4_1.pdf

Tinto, V. (1998). Colleges as communities: Taking research on student persistence seriously. The Review of Higher Education, 21(2), 167-177.

Whatley, J., \& Ahmad, A. (2007). Using video to record summary lectures to aid students' revision. Interdisciplinary Journal of Knowledge and Learning Objects, 3, 185-196. Retrieved from http://ijklo.org/Volume3/IJKLOv3p185-196Whatley367.pdf

Wheeler, S., Yeomans, P., \& Wheeler, D. (2008). The good, the bad and the wiki: Evaluating studentgenerated content for collaborative learning. British Journal of Educational Technology, 39(6), 987 995. doi:10.1111/j.1467-8535.2007.00799.x

Wieling, M. B., \& Hofman, W. H. A. (2010). The impact of online video lecture recordings and automated feedback on student performance. Computers \& Education, 54 (4), 992-998.

Wishart, C., \& Guy, R. (2009). Analyzing responses, moves, and roles in online discussions. Interdisciplinary Journal of E-Learning and Learning Objects, 5, 129-144. Retrieved from http://ijklo.org/Volume5/IJELLOv5p129-144Wishart658.pdf

Woodley, A. (2004). Conceptualizing student dropout in part-time distance education: Pathologizing the normal? Open Learning, 19(1), 47-63.

Zhang, D., Zhou, L., Briggs, R. O., \& Nunamaker, J. F. Jr. (2006). Instructional video in e-learning: Assessing the impact of interactive video on learning effectiveness. Information \& Management, 43 (1), $15-27$.

\section{Biography}

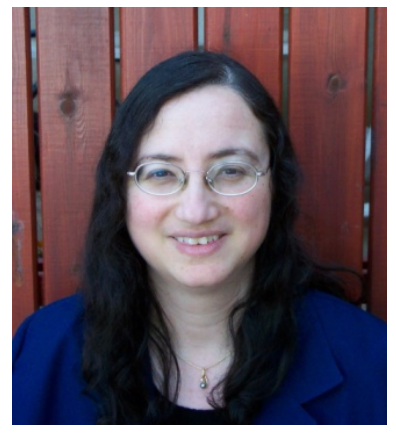

Nitza Geri is Head of the Department of Management and Economics, the Open University of Israel and a member of the Research Center for Innovation in Learning Technologies. She holds a B.A. in Accounting and Economics, an M.Sc. in Management Sciences and a Ph.D. in Technology and Information Systems Management from Tel-Aviv University. Nitza is a CPA (Israel) and prior to her academic career she had over 12 years of business experience. Her research interests and publications focus on various aspects of the value of information, and information systems adoption and implementation, including strategic information systems, e-business, economics of information goods, attention economy, value creation and the Theory of Constraints, managerial aspects of e-learning systems adoption and use. Personal site: http://www.openu.ac.il/Personal sites/nitza-geri.html 